\title{
NUTRITIVE EVALUATION OF SAGO FIBRE
}

\author{
D. P. Yadav and M. Mahyuddin ${ }^{1}$ \\ Department of Animal Sciences \\ Faculty of Veterinary Medicine and Animal Sciences \\ University Pertanian Malaysia \\ 43400 UPM Serdang, Selangor, Malaysia
}

\begin{abstract}
Summary
Nutrient evaluation of sago fibre showed that the fibre has potential and could be utilized as feed for ruminants. However, as a source of nutrients, it has limitations arising from low intake, digestibility, crude protein and minerals content.

The present study showed that the sago fibre is low in crude protein $(3.3 \%)$ and high in neutral detergent fibre $(72.5 \%)$ and acid detergent lignin $(25.8 \%)$ contents. Treatment of sago fibre with urea increased the crude protein content from 3.3 to $16.7 \%$. Both urea and sodium hydroxide treatment decreased the neutral detergent fibre level from 72.5 to 59 and $56.6 \%$, respectively.

Rumen degradation of sago fibre by nylon bag showed that both urea and sodium hydroxide treatments increased dry matter and organic matter disappearance of the fibre significantly. In vivo digestibility of $2 \%$ urea treated sago fibre was $47.5 \%$ and intake of the fibre was $1.57 \%$ of body weight of the lamb.
\end{abstract}

(Key Words: Sago Fibre, Digestibility, Alkali Treatment, Ensiling, Nutrient Composition)

\section{Introduction}

Feeding systems utilizing agro-industrial byproducts could serve two useful purposes, viz reducing the rate of pollution and providing new sources of feedingstuffs for livestock. More than 47,000 tonnes of sago fibre is produced annually in Malaysia. The sago fibre, a by-product from the extraction of sago starch, has not been used as animal feed. However, Jalaludin (1987) suggested that sago fibre might be utilized as feeds for ruminants.

Like many other agricultural by-products, sago fibre is high in lignified fibre and low in other essential nutrients (Jalaludin et al., 1970). Evidence indicates that the major component of this byproduct is cell wall polysaccharides which are not well utilized by the animal. Methods which increase the utilization of this component would certainly increase the nutritive value of this resi-

\footnotetext{
${ }^{1}$ Address reprints requests to Professor (Dr.) M. Mahyuddin, Department of Animal Sciences, Faculty of Veterinary Medicine and Animal Sciences, University Pertanian Malaysia, 43400 UPM Serdang, Selangor, Malaysia.

Received December 24, 1990

Accepted April 9, 1991
}

due. Like other fibrous residues, pretreatment with chemical may improve its nutritive value (Ibrahim, 1983). Sodium hydroxide and urea are the most common chemicals used for improving the feeding values of fibrous feed (Doyle et al., 1986).

This study is aimed a) determine the nutrient composition, degradibility and digestibility of sago fibre and b) assess the effect of alkali pretreatment on the nutritive value of sago fibre.

\section{Materials and Methods}

\section{Sago Fibre}

Six $\mathrm{kg}$ sun dried sago fibre was allocated to each of the following treatments: 2, 5 and $6 \mathrm{~g}$ Urea/100 g DM fibre. Each group of sago fibre was sprayed with a urea solution using a garden watering can $(1: 1 \mathrm{w} / \mathrm{v})$ and then ensiled in double plastic bags for 1, 2, 3 and 4 weeks for each treatment. Similar procedure was applied for sodium hydroxide treatment, where the sago fibre was sprayed with $\mathrm{NaOH}$ solution of 2, 4 and $6 \mathrm{~g} \mathrm{NaOH} / 100 \mathrm{~g} \mathrm{DM}$ fibre, and then ensiled in doubled plastic bags for $1,2,3$ and 4 weeks for each treatment. The "control" treatment were untreated sago fibre, sprayed with water 1:1 (w/v). 
Analytical Methods

At the end of the ensiled period, the treated fibre was immediately analysed for crude protein (CP) by micro-kjeldahl method. All chemical analyses were carried out in duplicates. The samples were dried in forced air oven at $60{ }^{\circ} \mathrm{C}$ till constant weight, ground and stored for analysis. Dry matter (DM) was determined in forced air oven at $105^{\circ} \mathrm{C}$ overnight. Ashing was carried out at $550^{\circ} \mathrm{C}$ overnight.

Neutral detergent fibre (NDF), acid detergent fibre (ADF), cellulose, hemicellulose, silica and acid detergent lignin were determined by the method described by Goering and Van Soest (1970). Ether extract was analysed by refluxing with petroleum ether. Calcium $(\mathrm{Ca})$, copper $(\mathrm{Cu})$ and magnesium $(\mathrm{Mg})$ was determined by atomic absorption spectrophotometer and phosphorus by a single-beam spectrophotometer. Gross calorific value (GE) of sago fibre was determined using an Adiabatic Bomb Calorimeter. All methods for analyses were those recommended by the A.O.A.C. (1980).

\section{Nylon bag technique}

The method used was essentially that of Mehrez and Orskov (1977). Three grammes of sample were placed in nylon bags $(9 \times 15 \mathrm{~cm})$ and suspended in the rumen of 3 cannulated sheep fed with a basal ration of sago fibre supplemented with $200 \mathrm{~g}$ corn, $50 \mathrm{~g}$ fish meal and $20 \mathrm{~g}$ mineral mix. For each sample, two successive incubation of $48 \mathrm{~h}$ were carried out in 3 sheep to give 6 measurements for each sample. After incubation in the rumen for $48 \mathrm{~h}$, the contents of the nylon bags were washed and dried at $60^{\circ} \mathrm{C}$ till constant weight. The residues in the bags were transferred into porcelain crucible and ashed at $550^{\circ} \mathrm{C}$ overnight. The proportion of $\mathrm{DM}$ and OM which had dissappeared, were determined from the difference between amount before and after incubation.

\section{In vivo digestibility}

Four male sheep (20-23 kg liveweight) of Malin $\times$ Dorsett crossbred were housed in individual metabolic crates and had continuous access to water. Prior to the commencement of the experiment, sheep were treated with antihelmintics and allowed 3 weeks adaptation period to the experimental diet.
The sheep were given a basal diet of sago fibre treated with $2 \%$ urea, ensiled for 2 weeks, $50 \mathrm{~g}$ molasses and $20 \mathrm{~g}$ mineral premix (Lazuli Co. Ltd., Kuala Lumpur) ad libitum. The sheep were fed once daily at 09:00 h, the amount offered was at least $20 \%$ in excess of the previous days intake. The voluntary feed intake and total faecal output were measured over the last 10 days. Samples of feed offered and refused were collected, weighed and sub-sampled daily and 10\% were kept for DM and OM determinations.

The DM and OM digestibility (DMD, OMD), and intake (DMI, OMI) was calculated from the $\mathrm{DM}$ and $\mathrm{OM}$ of sago fibre eaten and excreated by the animal (Minson, 1981).

The analysis of variance (Steel and Torrie, 1960) was carried out using the Statistical Analysis System (SAS) installed on micro computer.

\section{Results and Discussion}

The chemical composition of sago fibre is shown in table 1. Sago fibre was low in $\mathrm{CP}$ $(2.9 \%)$ and high in NDF $(72.8 \%)$ content. The fibre was also fairly high in $\mathrm{ADF}(38.7 \%)$, ADL $(25.7 \%)$, and low in $\mathrm{Ca}(0.2 \%)$ and $\mathrm{P}(0.1 \%)$. The chemical composition of sago fibre was comparable to other fibrous agricultural by-products such as rice straw and palm press fibre (PPF). Rice straw contained CP (3-6\%), NDF (61-86\%) ADF (41-63\%) and ADL (4-10\%) (Doyle et al., 1986). PPF also contained CP (4\%) and NDF (75.4\%) as mentioned by Devendra (1978), were similar to sago fibre.

The urea and sodium hydroxide treatments had significant effect on NDF and CP content of the sago fibre (table $2 \& 3$ ). Urea treatment decreased the NDF content of the fibre with increasing length of ensiling period. This was probably because of time taken in converting urea to ammonium hydroxide (Sundstol et al., 1978; Jayasuriya and Pearce, 1983; Wanapat, 1985). The NDF content of sago fibre was also decreased with increasing level of alkali used (Jackson, 1977; Chairatanayuth and Wannamolee, 1987).

Urea treatment increased the CP content of sago fibre significantly due to the $\mathrm{N}$ from urea. The concentration of $\mathrm{N}$ also increased with the strength of urea used (table 3). Similar results had been reported by many workers with straws where $0.3-4.2 \% \mathrm{~N}$ increased over untreated straw 
TABLE 1. THE CHEMICAL COMPOSITION OF UNTREATED SAGO FIBRE

\begin{tabular}{|c|c|c|c|}
\hline & Range & Mean & S.E. \\
\hline Moisture (\%) & $45.5-73.5$ & & \\
\hline Ash (\% DM) & $8.5-9.2$ & 8.8 & 0.20 \\
\hline CP (\% DM) & $2.6-3.2$ & 2.9 & 0.30 \\
\hline Ether Extract $(\%$ DM) & $3.4-3.7$ & 3.5 & 0.90 \\
\hline Gross Energy $(\mathrm{MJ} / \mathrm{kg} \mathrm{DM})$ & $12.3-15.9$ & 13.7 & 1.10 \\
\hline NDF (\% DM) & $69.3-74.5$ & 72.8 & 0.30 \\
\hline $\mathrm{ADF}(\% \mathrm{DM})$ & $37.0-41.7$ & 38.7 & 1.49 \\
\hline Cellulose (\% DM) & $4.9-6.0$ & 5.3 & 0.36 \\
\hline Hemicellulose (\% DM) & $32.3-36.1$ & 33.7 & 1.18 \\
\hline Silica $(\%$ DM) & $5.7-7.8$ & 6.8 & 0.61 \\
\hline $\mathrm{ADL}(\% \mathrm{DM})$ & $23.8-27.7$ & 25.7 & 1.11 \\
\hline $\mathrm{Ca}(\mathrm{mg} / \mathrm{g} \mathrm{DM})$ & $1.7-2.8$ & 2.2 & 0.31 \\
\hline $\mathrm{P}(\mathrm{mg} / \mathrm{g} \mathrm{DM})$ & $1.2-1.5$ & 1.3 & 0.10 \\
\hline $\mathrm{Mg}(\mathrm{mg} / \mathrm{g} \mathrm{DM})$ & $0.3-0.7$ & 0.5 & 0.11 \\
\hline $\mathrm{Cu}(\mu \mathrm{g} / \mathrm{g}$ DM $)$ & $0.3-0.5$ & 0.4 & 0.06 \\
\hline
\end{tabular}

TABLE 2. EFFECT OF ENSILING PERIOD ON NDF CONTENT ( $g / 110 \mathrm{~g}$ DM) OF UNTREATED, UREA AND SODIUM HYDROXIDE TREATED SAGO FIBRE

\begin{tabular}{|c|c|c|c|c|c|c|c|}
\hline \multirow{2}{*}{ Chemical } & \multirow{2}{*}{$\begin{array}{c}\text { Level } \\
(\%)\end{array}$} & \multicolumn{4}{|c|}{ Ensiling Period (wks) } & \multirow{2}{*}{ Significance } & \multirow{2}{*}{ S.E. } \\
\hline & & 1 & 2 & 3 & 4 & & \\
\hline $\begin{array}{l}\text { Sago Fibre } \\
\text { (control) }\end{array}$ & - & 72.8 & 72.7 & 72.5 & 72.3 & NS & 0.2 \\
\hline \multirow[t]{3}{*}{ Urea } & 2 & 66.8 & 62.6 & 61.7 & 61.6 & $* * *$ & 0.6 \\
\hline & 4 & 65.1 & 61.8 & 61.6 & 60.4 & $* * *$ & 0.5 \\
\hline & 6 & 64.5 & 60.4 & 59.3 & 58.9 & $* * *$ & 0.6 \\
\hline \multirow[t]{3}{*}{$\mathrm{NaOH}$} & 2 & 61.8 & 61.2 & 60.6 & 60.5 & NS & 0.2 \\
\hline & 4 & 59.7 & 59.5 & 59.0 & 58.9 & NS & 0.3 \\
\hline & 6 & 57.9 & 57.2 & 57.1 & 56.6 & NS & 0.3 \\
\hline
\end{tabular}

TABLE 3. EFFECT OF ENSILING PERIOD ON CP CONTENT ( $\mathrm{g} / 100 \mathrm{~g}$ DM) OF UNTREATED, UREA AND SODIUM HYDROXIDE TREATED SAGO FIBRE

\begin{tabular}{|c|c|c|c|c|c|c|c|}
\hline \multirow{2}{*}{ Chemical } & \multirow{2}{*}{$\begin{array}{c}\text { Level } \\
(\%)\end{array}$} & \multicolumn{4}{|c|}{ Ensiling Period (wks) } & \multirow{2}{*}{ Significance } & \multirow{2}{*}{ S.E } \\
\hline & & 1 & 2 & 3 & 4 & & \\
\hline $\begin{array}{l}\text { Sago Fibre } \\
\text { (control) }\end{array}$ & - & 3.2 & 3.2 & 3.2 & 3.2 & NS & 0.03 \\
\hline \multirow[t]{3}{*}{ Urea } & 2 & 10.4 & 10.5 & 10.3 & 10.4 & NS & 0.05 \\
\hline & 4 & 13.2 & 13.5 & 13.3 & 13.4 & NS & 0.08 \\
\hline & 6 & 16.5 & 16.5 & 16.8 & 16.9 & NS & 0.08 \\
\hline \multirow[t]{3}{*}{$\mathrm{NaOH}$} & 2 & 3.0 & 2.7 & 3.0 & 2.8 & NS & 0.06 \\
\hline & 4 & 2.9 & 3.0 & 2.7 & 2.8 & NS & 0.06 \\
\hline & 6 & 2.9 & 2.8 & 2.9 & 2.9 & NS & 0.06 \\
\hline
\end{tabular}


- ho: urea was applied at the level of $1-20 \mathrm{~g} /$ $100 \mathrm{~g}$ DM (Ambar and Djajanegara, 1982; Schiere et al., 1988). Sodium hydroxide treatment resulted in reduced $\mathrm{CP}$ content relative to untreated fibre, was probably due to chemical degradation of the protein into volatile compounds (Vijchulata et al., 1985). Ensiling period did not effect the CP content of the fibre.

Both urea and sodium hydroxide treatments increased the DM and OM disappearance from the nylon bag of sago fibre significantly with increasing level of chemical (table $4 \& 5$ ). This result was similar to results of treating straws. where there was an increase of 5-15 units of DM and $\mathrm{OM}$ disappearance from nylon bag when 1-20 g alkali per $100 \mathrm{~g}$ DM straw was used (Chandra and Jackson, 1971; Ambar and Djajanegara, 1982). The effect of ensiling period was significant in urea treated fibre because of time taken for converting urea to ammonium hydroxide. During the ensiling of fibre with urea, it is believed that ammonia released from urea forms ammonium hydroxide and this alkali breaks down ligno-cellulose bonds (Jackson, 1977; Chesson, 1981) resulting the fibre more susceptible to digestion by microbial enzymes.

The result of urea treatment on chemical composition and nylon bag degradation showed that $2 \%$ urea treated sago fibre, ensiled for 2 weeks was equally good in terms of chemical composition and nylon bag degradability. Thus, $2 \%$ urea treated fibre was further tested for in vivo digestibility. The urea treatment has the added advantage in that it also increased the $\mathrm{N}$ content thus stimulating rumen fermentation and providing the additional protein required by the animal. Urea improves feeding quality of the fibrous material without loading the feed with

TABLE 4. EFFECT OF ENSILING PERIOD ON DM DISAPPEARANCE ( $\mathrm{g} / 100 \mathrm{~g} \mathrm{DM}$ ) OF UNTREATED, UREA AND SODIUM HYDROXIDE TREATED SAGO FIBRE

\begin{tabular}{|c|c|c|c|c|c|c|c|}
\hline \multirow{2}{*}{ Chemical } & \multirow{2}{*}{$\begin{array}{c}\text { Level } \\
(\%)\end{array}$} & \multicolumn{4}{|c|}{ Ensiling Period (wks) } & \multirow{2}{*}{ Significance } & \multirow{2}{*}{ S.E. } \\
\hline & & 1 & 2 & 3 & 4 & & \\
\hline $\begin{array}{l}\text { Sago Fibre } \\
\text { (control) }\end{array}$ & - & 51.3 & 51.3 & 51.5 & 51.2 & NS & 0.3 \\
\hline \multirow[t]{3}{*}{ Urea } & 2 & 56.8 & 59.4 & 60.0 & 60.2 & * & 0.4 \\
\hline & 4 & 60.6 & 61.4 & 62.7 & 63.6 & $* *$ & 0.4 \\
\hline & 6 & 62.3 & 64.2 & 64.7 & 65.2 & $*$ & 0.4 \\
\hline \multirow[t]{3}{*}{$\mathrm{NaOH}$} & 2 & 61.1 & 60.9 & 61.8 & 61.8 & NS & 0.3 \\
\hline & 4 & 62.5 & 63.7 & 63.8 & 64.1 & NS & 0.3 \\
\hline & 6 & 64.8 & 65.7 & 66.8 & 66.8 & NS & 0.5 \\
\hline
\end{tabular}

TABLE 5. EFFECT OF ENSILING PERIOD ON OM DISAPPEARANCE ( $\mathrm{g} / 100 \mathrm{~g}$ OM) OF UNTREATED, UREA AND SODIUM HYDROXIDE TREATED SAGO FIBRE

\begin{tabular}{|c|c|c|c|c|c|c|c|}
\hline \multirow{2}{*}{ Chemical } & \multirow{2}{*}{$\begin{array}{l}\text { Level } \\
(\%)\end{array}$} & \multicolumn{4}{|c|}{ Ensiling Period (wks) } & \multirow{2}{*}{ Significance } & \multirow{2}{*}{ S.E. } \\
\hline & & 1 & 2 & 3 & 4 & & \\
\hline $\begin{array}{l}\text { Sago Fibre } \\
\text { (control) }\end{array}$ & - & 54.7 & 54.7 & 54.7 & 54.4 & NS & 0.2 \\
\hline \multirow[t]{3}{*}{ Urea } & 2 & 58.7 & 61.7 & 62.8 & 63.2 & $* *$ & 0.6 \\
\hline & 4 & 63.3 & 63.7 & 65.4 & 66.0 & $*$ & 0.4 \\
\hline & 6 & 64.9 & 66.0 & 67.7 & 68.9 & $* *$ & 0.5 \\
\hline \multirow[t]{3}{*}{$\mathrm{NaOH}$} & 2 & 64.3 & 63.3 & 63.6 & 63.8 & NS & 0.3 \\
\hline & 4 & 65.2 & 65.3 & 65.7 & 66.1 & NS & 0.3 \\
\hline & 6 & 67.2 & 67.2 & 68.3 & 68.8 & NS & 0.4 \\
\hline
\end{tabular}


excess sodium (as in the case of $\mathrm{NaOH}$ ), is economical, easily available and safe to handle (Horton, 1979; Schiere and Ibrahim, 1985).

The in vivo digestibility and intake of the treated fibre are shown in table 6. The mean DM digestibility was $575 \mathrm{~g} / \mathrm{kg}$ which is only sufficient to maintain ruminant (Doyle, 1982). Associated with this low digestibility was a low DM intake ( $1.48 \%$ of liveweight, $\mathrm{LW}$ ) possibly due to a slow digestibility of the cell mass. The low intake associated with the low dry matter digestibility meant that insufficient nutrients were absorbed to prevent the sheep losing weight during the in vivo trial.

\section{Conclusions}

The result of the study suggests that sago fibre

\section{TABLE 6. INTAKE AND DIGESTIBILITY OF $2 \%$ UREA TREATED SAGO FIBRE ENSILED FOR 2 WEEKS BY SHEEP}

\begin{tabular}{lcc}
\hline Parameter & Mean & S.E. \\
\hline No. of sheep & 4 & \\
Initial M $(\mathrm{kg})$ & 20.93 & \\
Final M (kg) & 20.45 & \\
Liveweight change $(\mathrm{kg})$ & -0.48 & \\
Fibre offered $(\mathrm{g} \mathrm{DM} / \mathrm{d})$ & 491.5 & \\
Fibre refused (g DM/d) & 186.1 & \\
\% of offered & 37.95 & 20.44 \\
Fibre DM intake & 305.4 & 0.73 \\
(g DM/d) & 14.7 & 1.69 \\
(g DM/kg M.d) & 31.4 & \\
(g DM/kg M0.75d) & & \\
Fibre DM digestibility & 575.2 & \\
(g/kg feed) & & \\
\hline
\end{tabular}

can be used as a maintenance feed for ruminant provided that is treated with urea to increase intake and digestibility. Protein and energy supplements appear to be required if animals fed treated sago fibre are required to grow.

\section{Acknowledgements}

The authors wish to thank the Department of Animal Sciences, University Pertanian Malaysia for funding this project. D.P. Yadav is especially grateful to Winrock International for supporing his stay at University Pertanian Malaysia.

\section{Literature Cited}

A.O.A.C. 1980. Official Methods of the Association of Official Analytical Chemist (13th ed.). A.O.A.C., Washington, D.C.

Ambar, A. R. and A. Djajanegara. 1982. The effects of urea treatment on the disappearance of dry matter and fibre of rice straw from nylon bags. In: Proceedings of the second annual meeting of the Australian-Asian Fibrous Agricultural Residues Research Network held at the University Pertanian Malaysia, Serdang. Malaysia, 3-7 May. 1982, pp. 81-86.

Chairatanayuth. P. and V. Wannamolee. 1987. The composition and digestibility of threshed sorghum head residue treated with urea or $\mathrm{NaOH}$. In: proceedings of the sixth annual workshop of the Australian-Asian Fibrous Agricultural Residues Research Network held in the University of the Philippines at Los Banos, 1-3 April. 1986. pp. 187-189.

Chandra, S. and M. C. Jackson. 1971. A study of various chemical treatments to remove lignin from coarse roughages and increase their digestibility. J. Agric. Sci. Camb. 77:11-17.

Chesson, A. 1981. Effects of sodium hydroxide on cereal straws in relation to the enhanced degradation of structural polysaccharides by ruman microorganisms. J. Sci. Food Agric. 32:745-758.

Devendra, C. 1978. Utilization of feedingstuffs from oil palm. In:Proceedings of symposium held at the Faculty of Medicine, National University of 
Malaysia. Kuala Lumpur. Malaysia, 17-19 Oct., 1977. Malaysian Society of Animal Production. Serdang. pp. 116-131.

Doyle. P. T. 1982. Options for the treatment of fibrous roughages in developing countries. a review. In: Proceedings of the second annual meeting of the Australian-Asian Fibrous Agricultural Residues Research Network held at the University Pertanian. Serdang, Malaysia, 3-7 May. 1982. University of Melbourne Printing Services. Parkville. Australia. pp. 129-150.

Doyle. P. T.. C. Devendra and G. R. Pearce. 1986. Rice straw as a feed for ruminants. Canberra: International Development Program of Australian Universities and Colleges Limited, pp. 50-107.

Goering. H. K. and P. J. Van Soest. 1970. Forage fiber analysis agricultural handbood No. 379. Washington, D.C.: ARS/USDA.

Horton. G. M. J. 1979. Feeding value of rations containing non-protein nitrogen or natural protein and of ammoniated straw for beef cattle. J. Anim. Sci. 48:38-44.

Ibrahim. M. N. M. 1983. Physical, chemical, physico-chemical and biological treatments of crop residues. In: Australian Development Assistance Bureau Research for Development Seminar Three. Los Banos, Philippines, 18-23 May. 1981. Australian Government Publishing Service. Canberra. pp 53-68.

Jackson, M. G. 1977. The alkali treatment of straws. Review Article. Anim. Feed Sci. Technol. 2:105 -130 .

Jalaludin. S. 1987. Feedingstuffs for livestock in Malaysia: Progress on research and development. In: Proceedings of the Tenth Annual Conference of the Malaysian Society of Animal Production. pp. 73-80.

Jalaludin. S., W. C. Wong, M. Anuwar and G. C. Ching. 1970. Utilization of sago for growth in the fowl. Malays. Agric. J. 47(4):492-498.

Jayasuriya, M. C. N. and G. R. Pearce. 1983. The effect of urease enzyme on treatment time and the nutritive value of straw treated with ammonia as urea. Anim. Feed Sci. Technol. 8:271-281.

Mehrez, M. A. and E. R. Orskov. 1977. A study of the articifial fibre bag technique for determining the digestibility of feeds in the rumen. J. Agric. Sci. Camb. 88:645-649.

Minson, D. J. 1981. The measurement of digestibility and voluntary intake of forages with confined animals. In: Forage evaluation concepts and techniques. J. A. Wheeler and R. D. Mochrie (Ed.). AFGC/CSIRO pp. 159-174.

Schiere, J. B. and M. N. M. Ibrahim. 1985. Recent research and extension on rice straw feeding in Sri Lanka: A Review. In: Proceedings of the Fourth Annual Workshop of the Australian-Asian Fibrous Agricultural Residues Research Network held in Khon Kaen. Thailand, 10-14 April, 1985. International Development Program of Australian Universities and Colleges Limited. Canberra, pp. 116-126.

Steel, R. G. D. and J. H. Torrie. 1960. Principles and Procedures of Statistics. New York: McGraw-Hill Book Company.

Sundstol. F. and E. M. Coxworth and D. N. Mowat. 1978. Improving the nutritive value of straw and other low-quality roughages by treatment with ammonia. World Anim. Reg. 26:13-21.

Vijchulata, P., M. Mahyuddin and S. Sivarajasingam. 1985. Effect of ammonium hydroxide treatment on nutritive value of palm press fibre in buffalo and cattle. Malays. Appl. Biol. (14) 13-17.

Wanapat, M. 1985. Improving rice straw quality as ruminant feed by urea-treatment in thailand. In: Proceedings of an International Workshop held in Khon Kaen, Thailand, Nov. 29-Dec. 2, 198 4. pp. $147-175$.

Wanapat, M. 1987. Effects of concentration of urea. addition of salt and form of urea treated rice straw on intake and digestibility. In: Proceedings of the Sixth Annual Workshop of the AustraliaAsian Fibrous Agricultural Residues Research Network held in the University of the Philippines at Los Banos, 1-3 April, 1986. pp. 177-180.

Weston, R. H. 1984. Principles of feed intake control in ruminants given roughages. In: Proceedings of the Third Annual Workshop of the Australian-Asian Fibrous Agricultural Residues Research Network heid at the University of Peradeniya, Peradeniya, Sri Lanka, 17-22 April, 1983. pp. 14 -27 . 